\title{
CZERKIESKI RUCH NARODOWY: EMIGRACJA - DIASPORA - TRANSNACJONALIZM
}

\author{
CIRCASSIAN NATIONAL MOVEMENT: EMIGRATION, DIASPORA, \\ TRANSNATIONALISM
}

\begin{abstract}
The purpose of this article is to give an account of historical development of Circassian nationalism. The author proposes a modernist and ethno-symbolist perspective in research on national idea of Caucasian ethnic group divided in Stalinist USSR as a result of national engeneering, as well as by nineteenth century conquest of North Caucasus. The category of 'trans-nationalism' is based on Arjun Appadurai's understanding of development of various social and cultural identities in the globalising world. The case of Circassians living in North Caucasus and diaspora is viewed in this perspective. Thus, the article has a historical and anthropological scope and discusses Circassian nationalism in the past two centuries.
\end{abstract}

Key words: Circassians; Circassian nationalism; transnationalism; diaspora

\section{STRESZCZENIE}

Celem artykułu jest przybliżenie historycznego rozwoju nacjonalizmu czerkieskiego. W badaniach nad tożsamością pochodzącej z Kaukazu Północnego grupy etnicznej autor proponuje perspektywę modernistyczną i etnosymboliczną. Czerkiesi zostali podzieleni na odrębne grupy w wyniku stalinowskiej inżynierii narodowej. Wcześniej znaczna ich grupa została wygnana z Kaukazu podczas rosyjskiego podboju regionu.

MATEUSZ CHUDZIAK Instytut Wschodni Uniwersytetu Adama Mickiewicza w Poznaniu. Correspondence: mateusz87chudziak@gmail.com

This is an Open Access article distributed under the terms of the Creative Commons Attribution 3.0 PL License (creativecommons.org/licenses/by/3.0/pl/), which permits redistribution, commercial and non-commercial, provided that the article is properly cited. (C) The Author(s) 2015.

Publisher: Institute of Slavic Studies PAS [Wydawca: Instytut Slawistyki PAN] 
Potomkowie wygnańców tworzą dziś diasporę, której poświęcono najwięcej miejsca. Współczesna tożsamość Czerkiesów żyjących w diasporze i na Kaukazie została ujęta w ramy zjawiska zwanego w tekście „transnacjonalizmem". Kategoria ta oparta jest na rozumieniu nowoczesnych tożsamości społecznych proponowanemu przez Arjuna Appaduraia. W takiej perspektywie omawiana jest historia czerkieskiego nacjonalizmu w ostatnich dwóch stuleciach.

Stowa kluczowe: Czerkiesi; nacjonalizm czerkieski; transnacjonalizm; diaspora

\section{WPROWADZENIE}

$\mathrm{N}$ a Kaukazie Północnym, będącym jednym z najbardziej zróżnicowanych etnicznie regionów świata, nakreślenie spraw związanych ze współczesną tożsamością narodową wydaje się rzeczą kluczową. Jednak uchwycenie tego problemu nastręcza badaczowi niemałych kłopotów. Radziecki system inżynierii etnicznej i narodowej odcisnął swoje piętno na tym regionie. W rozmaitych pracach widzimy, że takie kategorie jak „narodowy”, "narodowościowy”, „etniczny" używane są w sposób intuicyjny, a niekiedy nawet powielają język wprowadzony przez bolszewików w latach dwudziestych ubiegłego stulecia. Władze radzieckie arbitralnie rozdzielały poszczególnym grupom etnicznym miano "narodu” (nacyja), "ludu” (narod) czy "narodowości” lub "grupy etnicznej" (narodnost). Bałagan pojęciowy widoczny jest również w oficjalnych dokumentach, co doskonale oddaje rozpoczynające preambułę rosyjskiej konstytucji określenie "My - mnogonacyjonal'nyj narod Rossijskoj Fiedieracyi" (Konstitutsiia Rossilskol Federatsii, b.d.). Uporządkowanie tego rozgardiaszu jest rzeczą niezbędną przy omawianiu problematyki związanej z czerkieskim nacjonalizmem. Pisząc na ten temat, posługuję się koncepcjami modernizmu i etnosymbolimu. Odrzucam tym samym esencjalne rozumienie tego, czym jest wspólnota narodowa. Po pierwsze dlatego, że przywołane przeze mnie koncepcje są dobrze ugruntowane we współczesnej humanistyce, a po drugie dlatego, że esencjalizm (prymordializm) jest podejściem dominującym w rozprawach uczonych rosyjskich i kaukaskich. Mam świadomość, że takie postawienie sprawy i argumentacja narażają na zarzut świadomego pominięcia perspektywy samych zainteresowanych, poprzez narzucenie własnych kategorii poznawczych badanej grupie -- aż po karygodną orientalizację. Muszę zatem zaznaczyć, że jestem od tego jak najdalej. Wykorzystuję prace badaczy pochodzenia kaukaskiego, ale jednocześnie mam pełną świadomość, że również w ich przypadku mamy do czynienia z tworzeniem naukowego dyskursu, który potem wykorzystywany jest do celów politycznych. Na całym Kaukazie kategorie „rdzenności”, a co za tym idzie odwiecznego i "naturalnego" prawa do zajmowania danych ziem, są przedmiotem żywej naukowej dyskusji, a historycy dowodzący takiego bądź innego pochodzenia danej grupy sami sytuują się w pozycji zaangażowanej.

To, kto i skąd pochodzi, nie może mnie zatem tutaj interesować. Jedyne, co chcę nakreślić, to rozwój i funkcjonowanie ideologii narodowej spajającej w mniejszym lub większym stopniu ludność żyjącą w takich republikach, jak Kabadryno-Bałkaria, Karaczajo-Czer-

1 Na gruncie rosyjskiej nauki antyesencjalne podejście najbardziej widoczne jest w pracach antropologów Walerija Tiszkowa i Wiktora Sznirelmana. Obaj zajmują się również nacjonalizmem na Kaukazie. Sznirelman zaś podkreśla fakt zaangażowania tamtejszych naukowców w reprodukcję narodowych historii, co czyni ich bezpośrednimi „producentami” upolitycznionej wiedzy (zob. Tishkov, 2000; Shnirel'man, 2003, 2006). 
kiesja i Adygea, oraz potomków czerkieskich wygnańców żyjących dzisiaj w diasporze. Jedynym, co ich łączy jest przekonanie o przynależności do wspólnoty wyobrażonej, która jednakże rozwija się nie wokół państwa, a tylko poszczególnych jednostek administracyjnych Federacji Rosyjskiej. Mieszkańcy tych autonomicznych republik dzielą wszakże przekonanie o wspólnocie z Czerkiesami żyjącymi w diasporze. Dlatego proponuję tutaj kategorię transnacjonalizmu, tj. takiej formy ideologii narodowej, która spaja różne społeczności żyjące w różnych miejscach na świecie. Takie podejście opieram na ustaleniach amerykańskiego antropologa Arjuna Appaduraia, dla którego tożsamości etniczne zasadniczo mają symboliczne znaczenie (Lewellen, 2013, s. 193). Autor ten kreśli wizję zaniku państw, a docelowo również nacjonalizmu, jednak zauważa, że we współczesnym zglobalizowanym świecie rozwój mediów i środków komunikacji może wpływać na rozwój tożsamości. Komentujący jego twórczość Ted Lewellen zauważa w tym pewną przesadę - zanik państw jako takich w możliwej do przewidzenia przyszłości jest mało realny, jednakże niewątpliwie rozwój globalizacji sprzyja powstawaniu nowych typów tożsamości, w tym również narodowych. Takie narody funkcjonują niejako poza i ponad państwami narodowymi (Lewellen, 2013, s. 206). W tej oto perspektywie chciałbym przedstawić zarys czerkieskiego nacjonalizmu, opisując kolejno jego historię, diasporę żyjącą na Bliskim Wschodzie (najlepiej znana jest mi diaspora turecka, stąd poświęcę jej najwięcej miejsca), w Europie Zachodniej i USA, oraz nacjonalizm w północnokaukaskich republikach. Powyżej opisany i - mam nadzieje wyjaśniony - problem pojęciowy wraca w przypadku każdej wspólnoty czerkieskiej w Rosji i diasporze. Dlatego szczegółowe problemy będe wyjaśniał w odniesieniu do konkretnej grupy lub grup.

\section{ZAŁOŻENIA NACJONALIZMU CZERKIESKIEGO, ETNONIMY, DIASPORA}

Współczesny nacjonalizm czerkieski rozwija się za sprawą działalności dwóch organizacji. Pierwszą jest Adyge Chase, mająca swoje oddziały w Kabardyno-Bałkarii, Karaczajo-Czerkiesji, Adygei oraz w Kraju Krasnodarskim. Działacze diaspory zorganizowani są wokół Międzynarodowego Stowarzyszenia Czerkieskiego. Obie te organizacje dążą do uznania rosyjskiego podboju Kaukazu w XIX w. za ludobójstwo, umożliwienia repatriacji na Kaukaz potomków wygnańców, a docelowo - do utworzenia zjednoczonej Czerkiesji w ramach Federacji Rosyjskiej (Nefliasheva, 2012b).

Etnonim „Czerkies" w Turcji i na całym Bliskim Wschodzie ma zbiorczy charakter. Określenie to, w myśl wytycznych Rosyjskiej Akademii Nauk, dotyczy wszystkich grup etnicznych określających się etnonimem Adyge oraz Szapsugów. W skład tego narodu wchodzą następujące subetnosy: Adygejczycy, Kabardzyjczycy i Czerkiesi, zamieszkujący autonomiczne republiki, w których są narodami tytularnymi. Toponim „Czerkiesja” natomiast odnosi się do terenów zamieszkanych przez wyżej wymienione grupy na terytorium rosyjskiego Kaukazu (Arutiunov, 2010). W potocznym tureckim rozumieniu etnonim Çerkes odnosi się natomiast do wszystkich obywateli Turcji pochodzących z Kaukazu Północnego. Niekiedy w pracach naukowych można dostrzec, że jest to powielane przez samych uczonych. Zdarza się bowiem, że wyżej wymienione grupy traktowane są jako "plemiona" wchodzące w skład narodu czerkieskiego obejmującego również Czeczenów czy Inguszy².

2 Ten pospolity błąd pojawia się między innymi w wartościowych skądinąd artykułach tureckiego antropologa Ayhana Kaya, które wykorzystuję w dalszej części pracy (Kaya, 2004, 2005). 
W artykule skupię się zatem na przedstawicielach grup etnicznych mówiących językami wchodzącymi w skład abchasko-adygejskiej grupy języków północnokaukaskich, którzy zawierają niekiedy pewne polityczne sojusze z innymi narodami Kaukazu.

Historia diaspory czerkieskiej w Turcji i na całym Bliskim Wschodzi sięga swoimi korzeniami średniowiecza. Kabardyjscy wojownicy zaciągali się do korpusu janczarów, a czerkieskie kobiety trafiały do osmańskich haremów³. Ponadto jedną z dynastii mameluckich w Egipcie założyli Czerkiesi (Gurguliia, b.d.).

Moim celem jest przybliżenie czerkieskiego nacjonalizmu w Turcji i innych krajach Bliskiego Wschodu. Konstytuuje go pamięć o utracie ojczyzny i emigracja do Imperium Osmańskiego. Swój wywód rozpoczynam od początków emigracji i jej dalszych losów.

\section{WOJNA KAUKASKA / MUCHADŻYRSTWO}

Jak wspomniałem na wstępie, początki nowoczesnego nacjonalizmu czerkieskiego sięgają rosyjskiego podboju Kaukazu, zakończonego w roku 1864 bitwą na Krasnej Polanie 4 . Wtedy to ostatni wojownicy na północnych stokach Kaukazu poddali się wojskom rosyjskim dowodzonym przez generała Nikołaja Iwanowicza Jewdokimowa. Dowódca ten ${ }^{5}$ uważał, że jedyną drogą do ostatecznego podbicia jest zastosowanie taktyki "spalonej ziemi". W wyniku działań rosyjskiej armii ogromna cześć mieszkańców północno-zachodniego Kaukazu zginęła lub została zmuszona do opuszczenia rodzinnych stron. Historycy często podkreślają ogromną skalę prześladowań, jakim została poddana ludność czerkieska, a także tragiczne skutki przymusowych przesiedleń. Czerkiesi migrowali do Imperium Osmańskiego przez cały okres wojny kaukaskiej. Największe fale uchodźców przypadły na lata ostatecznego podboju (1864 r.), a także wojny rosyjsko-tureckiej w latach 1877-1878. Charles King i Fasich Baderchan przywołują relacje brytyjskich i rosyjskich dyplomatów opisujących katastrofalne położenie wypędzonych do Turcji mieszkańców Kaukazu. Czerkiesi padali z głodu, wycieńczenia i chorób, a liczby ofiar niekiedy sięgały kilkuset dziennie (King, 2008, ss. 80-85; Baderkhan, 2001, ss. 22-34). Stephen Shenfield natomiast, mówi wprost o ludobójstwie (1999, ss. 149-163).

W sytuacji, gdy mamy obfitą literaturę na temat okoliczności, w jakich mieszkańcy Kaukazu zostali zmuszeni do opuszczenia rodzinnych stron, trudno „rozgrzeszać” stronę silniejszą. Należy jednak wziąć po uwagę ówczesny kontekst geopolityczny (Kaukaz znajdował się bowiem w krzyżowym ogniu rywalizacji Rosji, Turcji oraz Persji, a pośrednio również Imperium Brytyjskiego i Francji), ale także to, z kim wojska rosyjskie miały do czynienia. O roli, jaką wojowniczość, pogarda śmierci (wiążąca się niekiedy z samobójczo pojętą odwagą) i fizyczna przemoc odgrywają w kulturowej rzeczywistości Kaukazu, pisze Władimir Bobrownikow. Skupia się on przede wszystkim na północno-wschodniej części regionu, ale jego wnioski - co sam zaznacza - można zastosować dla znacznej części, jeśli nie całości Kaukazu (Bobrovnikov, 2000; por. Górecki, 2010, s. 168). Kluczowym poję-

3 Wyobrażenia mieszkańców Bliskiego Wschodu na temat Czerkiesów obojga płci jako obiektów seksualnych omawiane są w pracach Charlesa Kinga (2008, ss. 116-123) oraz Setenay Nil Doğan (2010).

4 Jego faktyczna intensyfikacja nastąpiła pod koniec lat osiemdziesiątych XX W., tj. W okresie pieriestrojki, jednakże, jak dowodzi Charles King, pierwsze „wynalazki” czerkieskiej tradycji narodowej powstały w okresie wojny kaukaskiej i wiążą się z działalnością wywiadowczą brytyjskiego szpiega Davida Urquharta, który zaprojektował czerkieski zielony sztandar z żółtymi strzałami i dwunastoma gwiazdami, obecnie będący flagą Republiki Adygei (King, 2007).

5 Podobnie jak generał Aleksiej Jermołow na wschodzie regionu. 
ciem, z jakim spotykamy się, obserwując przemoc na Kaukazie, jest abrecziestwo (wśród Czerkiesów zeklue - czer. - зекlyэ) - rodzaj „zinstytucjonalizowanego" bandytyzmu, którym parali się abrecy - młodzi nieżonaci mężczyźni; ich zadaniem było oddalenie się od rodzinnej wspólnoty na kilka lat. Abrecy zajmowali się łupiestwem, rozbojem i porwaniami. Taka działalność wiązała się z pomocą własnej wspólnocie, ale też miała charakter inicjacyjny (Marszewski, 2010). Młody wojownik (dżygit) w ten sposób zyskiwał autorytet. Formacja ta przetrwała do czasów współczesnych, zmieniając tylko formę. W okresie radzieckim wiązała się z nielegalną pracą w głębi Związku Radzieckiego (tzw. szabaszka), a w latach dziewięćdziesiątych XX w. i obecnie z wojną w Czeczenii oraz zaciąganiem się do poddziałów partyzanckich (Bobrovnikov, 2000; Marszewski, 2010; Nefliasheva, 2012d). Zdaniem Bobrownikowa nie ma jednak dowodów na to, że abrecziestwo było powszechne na Kaukazie przed pojawieniem się Rosjan (Bobrovnikov, 2000). Jeżeli przyjmiemy jego wersję, to w dalszym ciągu nierozwiązana pozostaje kwestia źródeł takiej formacji. Skoro abrieczestwo jest zjawiskiem na Kaukazie stosunkowo nowym, to jego ugruntowanie się musiało mieć przynajmniej częściowo swoją genezę w tradycyjnych wzorach postępowania. Warto się temu przyjrzeć, również dlatego że zakorzenione wśród Kaukazczyków w ogólności, a Czerkiesów w szczególności, normy i kodeksy mogły mieć znaczący wpływ na ich dalsze losy na emigracji.

Powoduje to, że struktura społeczna Kaukazu sprzed podboju była bardzo skomplikowana. Można określić ją jako swego rodzaju „demokrację wojenną". Walter Richmond twierdzi, że plemiona czerkieskie dzieliły się na dwa typy. Pierwszy z nich miał charakter "feudalny" i hierarchiczny z niewolnikami na samym dole drabiny społecznej, zwanymi z turecka kułami, chłopami, arystokracją - zróżnicowaną ze względu na urodzenie i majątek, oraz książętami, którzy pełnili funkcję patronów. Drugi typ plemion miał charakter "demokratyczny", a władza należała tu do wiecowego kolektywu zwanego chase. Prawo zabierania głosu podczas chase uzyskiwało się jednak nie wcześniej niż około czterdziestego roku życia (Richmond, 2008, ss. 20-26).

Biorąc pod uwagę wcześniejsze rozważania, można uznać, że dla młodych nieżonatych mężczyzn formą społecznej emancypacji było wspomniane już wcześniej zeklue - paralelne dla abrecziestwa, to jest forma uzawodowionego bandytyzmu, nosząca znamiona inicjacyjne. Dla większości plemion główną formą utrzymania, oprócz rolnictwa, była zatem grabież i rozbój. Rosjanie znaleźli w Czerkiesach zapalczywych przeciwników, a wybrana przez rosyjskich dowódców taktyka wydaje się być wyrazem tyle okrucieństwa i rasizmu, ile zwyczajnej bezsilności.

Ogromna większość Czerkiesów wyemigrowała zatem do Imperium Osmańskiego, ginąc po drodze z głodu i chorób. Straty są trudne do oszacowania, wahają się bowiem od 500 tys. do 2 mln (Baderkhan, 2001, ss. 33-34; King, 2008, s. 83). Ci, którzy ocaleli, określani są mianem muchadżyrów, czyli po arabsku emigrantów. Na ziemiach tureckich szybko uzyskali jednak specyficzny społeczny status.

\section{CZERKIESI W STRUKTURZE SPOLECZNEJ IMPERIUM OSMAŃSKIEGO I WSPÓtCZESNYCH PAŃSTW BLISKIEGO WSCHODU}

Ponieważ Czerkiesi mieli już w Turcji od kilku wieków wyrobioną „renomę" wyjątkowo hardych i bitnych, szybko zostali wcieleni w szeregi wojsk osmańskich. Wysoka Porta osiedlała ich na terenach zagrożonych buntami wojowniczych plemion kurdyjskich, 
Joruków (Turkmenów), czy arabskich Druzów oraz Beduinów (stąd diaspora czerkieska w innych krajach Bliskiego Wschodu). Ponadto, przesiedleńcy lokowani byli również na Bałkanach wśród chrześcijańskich poddanych suttana (Kushkhabiev, 2007). Propaganda osmańska wykorzystywała krzewione w tej części imperium przez Rosję idee panslawizmu przeciwko ich adresatom, przedstawiając Czerkiesom Bułgarów, czy Serbów jako pobratymców Rosjan, a zarazem sprzymierzeńców władzy carskiej. Stąd stosunki pomiędzy lokalną ludnością a przybyszami z Kaukazu były wrogie już od samego początku obecności muchadżyrów w europejskich posiadłościach Porty (Kushkhabiev, 2007). Podobną rolę odgrywali Kaukazczycy rozlokowani na ziemiach zamieszkanych przez wcześniej wspomniane grupy na Bliskim Wschodzie. Co prawda, nie wykorzystywano z oczywistych przyczyn różnic etnicznych, a tym bardziej religijnych, jednak ugruntowana przez tradycyjny honorowy kodeks (Adyge Chabze) lojalność muchadżyrów wobec nowego państwa-gospodarza pomagała Porcie utrzymywać w ryzach poddanych, których lojalność ulokowana była w osobach szejchów bądź przywódców plemion druzyjskich, joruckich czy beduińskich (Kushkhabiev, 2007). Czerkiesi stopniowo byli wcielani do regularnych wojsk. Jednocześnie przez całą niemal drugą połowę XIX stulecia aż do lat dwudziestych XX w. utrzymywały się oddziały nieregularne, funkcjonujące również na Bałkanach na równi z bandami tureckich zbójcerzy na usługach Porty, tzw. Baszybuzuków. Czerkiescy oficerowie szybko dosłużyli się generalskich szlifów i zyskiwali tytuł paszy. W ten sposób ugruntował się funkcjonujący już od czasów średniowiecza stereotyp Czerkiesa, będącego wyjątkowo lojalnym poddanym i sługą władzy suttańskiej. Znaczną rolę $w$ budowie takiego wizerunku odegrał wzmiankowany powyżej Adyge Chabze podkreślający wagę takich wartości jak wierność przysiędze, danemu słowu, czy honor. Szczególnie ostatnia z wymienionych wartości zasługuje na podkreślenie i ma wagę nieporównanie większą, aniżeli zwykło się przyjmować w naszym kręgu kulturowym.

Czerkiescy poddani Porty pod koniec XIX w. mieli również swój udział w pogromach Ormian. W latach dziewięćdziesiątych tego stulecia uformowano oddziały milicji sułtańskiej Hamidiye, nazwanej od imienia padyszacha - Abdulhamida II (Zürcher, 2013, s. 83). Składała się ona w znacznej mierze z Kurdów, a dowodzili nimi Czerkiesi. Hamidiye odegrały główną rolą w masakrach Ormian dokonanych we wschodniej Anatolii w latach dziewięćdziesiątych XIX w. Udział Czerkiesów w tamtych wydarzeniach związany był z tym, że ormiańscy nacjonaliści widzieli swojego protektora w Rosji. Nienawiść Czerkiesów względem Caratu została przeniesiona na Ormian.

W okresie republikańskim opinia o bitnych i lojalnych Czerkiesach była podtrzymywana. Potomkowie muchadżyrów nadal służyli w armii i piastowali odpowiedzialne funkcje polityczne. Warto wymienić tutaj postać Kazıma Karabekira, bliskiego współpracownika Kemala Atatürka, a później zasłużonego polityka republikańskiego. Wielkie kontrowersje budzi natomiast biografia Czerkiesa Ethema. W tureckiej i zachodniej historiografii uznawany jest on za awanturnika, który wraz ze swoją Zieloną Armią wspomagał turecki ruch oporu podczas Wojny o Niepodległość, wsławiąc się kilkoma efektownymi zwycięstwami nad wojskami zachodnich aliantów oraz Grekami. Ethem ostatecznie jednak odmówił zgody na włączenie swoich oddziałów do regularnej armii tureckiej i przeszedł na stronę Greków, po czym zbiegł do Jordanii, gdzie zmarł. Pod pewnymi względami historia Ethema wpisuje się jednak w pewien kaukaski schemat. Cały region bowiem odróżnia się

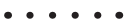

Postać Ethema budzi wielkie emocje w Turcji do dziś. Można pokusić się o stwierdzenie, że jednym z najczęstszych, jeśli nie najczęstszym określeniem jakie towarzyszy jego imieniu we współczesnym dyskursie publicznym, jest vatan hayini - "zdrajca ojczyzny" (Arseven, 2013). 
od otaczających go państw pewnym kulturowym przyzwoleniem na niepodporządkowanie się jakiejkolwiek zwierzchności. Nie chodzi tutaj o romantyczne umiłowanie wolności, ale raczej o kod kulturowy typowy dla tradycyjnie egalitarnych wojowniczych wspólnot, które w swojej wyobraźni politycznej nie uznają żadnego zwierzchnictwa. Mimo podkreślanych już wyżej kwestii związanych z tradycyjnym kodeksem honorowym, nie należy traktować takiego wyłamania się za aberrację, a raczej za składnik kultury i obyczaju kaukaskich wspólnot, niekiedy objawiający się w postaci zupełnie irracjonalnych na pierwszy rzut oka zachowań. Podobne cechy zaobserwować można bowiem u afgańskich Pasztunów, gdzie chan jest jedynie - jak pisze Jolanta Sierakowska-Dyndo - „pierwszym z równych", a wspólnota plemienna ma strukturę koła (egalitarną, z chanem w centrum jako opiekunem bardziej aniżeli władcą), przeciwstawną wobec struktury piramidy - bractwa sufickiego - z pirem na szczycie (Sierakowska-Dyndo, 2007, 2008, ss. 5-6). Dlatego też historia Czerkiesa Ethema, choć z pozoru paradoksalna, zdaje się doskonale wpisywać w określony wzorzec postępowania?

Mimo wszystko jednak wspomniany już wcześniej, mający długi rodowód stereotyp lojalnego Czerkiesa utrwalił się w republikańskiej Turcji. Czerkiesi bowiem mieli istotny wkład w przemiany polityczne, jakie dokonały się zarówno za rządów reżimu młodotureckiego (1908-1920), jak i w czasie tworzenia Republiki Tureckiej. W bliskim otoczeniu Mustafy Kemala znajdowali się Kazım Karabekir (później przeszedł do opozycji), Bekir Sami, Hüseyin Rauf, Hakkı Behiç, Mümtaz Ökmen, czy Ibrahim Süreyya (Kushkhabiev, 2007).

W pozostałych krajach Bliskiego Wschodu Czerkiesi pełnili podobne funkcje jak w Turcji. Największa ich wspólnota zamieszkuje Syrię (ok. 70-120 tys.), dalej Jordanię i Izrael (Nefliasheva, 2012c). W Syrii Adygowie postrzegani byli jako lojalni wobec reżimu Hafeza al-Assada, a później jego syna Baszara. Tradycyjnie służyli w armii i innych służbach mundurowych. Od lat dziewięćdziesiątych minionego stulecia zajmowali jednak w armii syryjskiej rangi co najwyżej średniego szczebla (Nosova, 2012). Ponadto, syryjscy Czerkiesi do momentu wybuchu krwawej wojny domowej w 2011 r. stanowili elitę kulturalną i naukową. Wielu z nich było pisarzami, aktorami, lekarzami, teologami muzułmańskimi. Wcześniej pewna część ludności pochodzenia kaukaskiego zajmowała się rolnictwem, co miało zdaniem Naimy Nieflaszewej, znaczny wpływ na rozwój gospodarki (Nefliasheva, 2012a). Wojna domowa skomplikowała sytuację mniejszości czerkieskiej na tyle, że zaczęto czynić starania o umożliwienie repatriacji na Kaukaz Północny. Oficjalnej akcji repatriacyjnej nie podjęto, jednakże władze poszczególnych republik autonomicznych i działacze Adyge Chase podejmowali takie starania. Wyznaczono kwoty dla repatriantów. Jak dotąd na Kaukaz przyjechało ok. 1000 osób. Wielu z nich własnym sumptem, jednak po drodze zaczęły pojawiać się kolejne problemy. Nie wszyscy repatrianci znają czerkieski, mało kto mówi po rosyjsku, niektórzy mają jedynie czasowe wizy. W tym kontekście ideologia narodowa wywołuje poczucie obowiązku pomocy wobec członków wspólnoty, którzy znaleźli się poza historyczną ojczyzną. Starania o umożliwienie repatriacji i mimo wszystko skromna pomoc mają zatem wymiar humanitarny.

Inaczej wygląda sytuacja Czerkiesów w Jordanii i Izraelu. Są to niewielkie wspólnoty bardzo silnie manifestujące swoją odrębność. W obu krajach nawet młode pokolenie

\section{......}

Tutaj też można dopatrywać się analogii z tradycją afgańską. W jednym z klasycznych już dzisiaj dla polskiej iranistyki artykułów Jadwiga Pstrusińska zwraca uwage na wbudowany w prawo zwyczajowe szowinizm, referując, że "żaden Pasztun nigdy nie uzna nikogo za lepszego od siebie, ani nawet za równego sobie" (Pstrusińska, 1977, ss. 63-79). Możemy przypuszczać, że Ethem, przywódca Zielonej Armii, odnoszącej sukcesy militarne mógt kierować się podobnymi pobudkami i nie uznawać władzy Mustafy Kemala. Na temat współczesnej kaukaskiej ksenofobii zob. reportaż Iwony Kaliszewskiej i Macieja Falkowskiego (2010, ss. 161-171). 
posługuje się ojczystym językiem. W Jordanii młodzi Czerkiesi mają możliwość nauki w mowie przodków. Status tej wspólnoty jest bardzo wysoki również ze względu na fakt, że gwardia królewska składa się właśnie z Czerkiesów. Jordania jest królestwem haszymickim. Rodzina królewska wywodzi swoje pochodzenie z rodu proroka Muhammada i pochodzi z Hidżazu. Czerkiesi stanowią osobną grupę „pretorian” strzegących króla. W Izraelu natomiast Adygowie zamieszkują kilka wiosek na Wzgórzach Golan. Również manifestują swoją odrębność, a w ich politycznej wyobraźni Kaukaz zajmuje szczególne miejsce jako historyczna ojczyzna, do której mają nadzieję powrócić (Bram, 1999). Ostatnia kwestia jest o tyle istotna, że pozwala nam w tej chwili płynnie przejść do problemu nacjonalizmu diaspory.

\section{NACJONALIZM DIASPORY CZERKIESKIEJ}

Typ nacjonalizmu, jaki reprezentuje diaspora czerkieska, rozpatrywać można na kilka sposobów. Klasyk studiów nad tym zjawiskiem, Ernest Gellner, wyodrębnił nacjonalizm diaspory jako oddzielny od nacjonalizmu państwowego i etnicznego (2009, ss. 200-210). Mimo iż od pierwszego wydania jego pracy upłynęło już ponad 30 lat, skonstruowana przezeń teoria zachowuje aktualność wobec omawianego tematu. Jego zdaniem wspólnoty etniczne przebywające w obcym kulturowo (a więc etnicznie - te pojęcia są dla Gellnera tożsame) środowisku zawsze pełniły specyficzne funkcje. Władze wykorzystywały ich konkretne umiejętności, im tylko właściwe. Można wymienić tutaj Żydów, Greków, Parsów czy Ormian, którzy uzyskali określoną pozycję ekonomiczną bądź zostawali urzędnikami. W tym ostatnim przypadku zasadniczą zaletą wykorzystania przez władze danej mniejszości do konkretnych celów była pewność, że mniejszość pozostanie lojalna i zachowa dystans wobec ogółu społeczeństwa, które nie będzie upatrywać w nich protektorów. Taka pozycja miała swoją cenę. Mniejszość nie mogła liczyć na ochronę, co z kolei wzmagato poczucie solidarności, przynajmniej w kontaktach z wrogą większością (Gellner, 2009, ss. 206-209). Takie wspólnoty dały początek narodom żyjącym w diasporze.

W przypadku Czerkiesów warto zwrócić uwage na ich pozycję w strukturze społecznej państwa tureckiego, którą można uznać za podobną do tej, którą pełnili Żydzi, Ormianie czy Grecy, zajmujący się działalnością kupiecką. Osobliwość Czerkiesów natomiast, o czym była już wcześniej mowa, przejawiała się w ich bojowości, co czyniło z nich doskonałych żołnierzy i oficerów. Jednocześnie w obliczu prowadzonej przez Portę polityki względem mniejszości Adygowie pozostawali w napiętych stosunkach z większością niekaukaskich grup etnicznych zamieszkujących państwo osmańskie. Czerkieska świadomość narodowa w Turcji wykształciła się zatem w oparciu o obcość względem odmiennej etnicznie i językowo większości tureckiej oraz innych mniejszości. Zadziwiająco nikłą rolę w kształtowaniu się zarówno czerkieskiego jak i innych nacjonalizmów odegrał jednak islam. Kluczem do stworzenia poczucia wspólnoty były wyżej wymienione różnice, o czym świadczy fakt, że w okresie rządów Młodoturków (1908-1920) w Stambule wydawano gazety w języku czerkieskim, a także funkcjonowały szkoły, w których ten język był wykładowym (Kushkhabiev, 2007).

W początkowym okresie swoich rządów modernistycznie i świecko zorientowane władze obiecywały autonomię licznym mniejszościom narodowym i etnicznym. Religia była pomijana. Zarówno Czerkiesi jak i Turcy nie przywiązywali - przynajmniej w deklaracjach 
- wielkiej wagi do islamu, który mógł stanowić tylko jeden z wielu składników tożsamości. Sytuacja zmieniła się diametralnie w późniejszym okresie rozwoju nacjonalizmu tureckiego, w czasie rządów tzw. Triumwiratu (1913-1918). Wtedy, mimo świeckich deklaracji ruchu młodotureckiego, zaczęto pojmować wspólnotę narodową w oparciu o dotychczasowe osmańskie millety - wspólnoty religijne. Wobec takiego pojęcia nowoczesne wspólnoty nietureckie, ale muzułmańskie grupy etniczne zostały włączone w skład narodu tureckiego. Tego typu koncepcję nowoczesnego nacjonalizmu przejęły świeckie elity kemalistowskie. Republikański nacjonalizm miał zastąpić islam, jako czynnik spajający. Mimo iż zakładano, że każdy obywatel Turcji jest Turkiem, nie sposób uznać nacjonalizmu tureckiego za "obywatelski” i inkluzywny. Kemaliści pojmowali wspólnotę narodową przede wszystkim w kategoriach etnicznych, a mówiąc modernistycznymi kategoriami lat dwudziestych XX w. - rasowych. Tureckie narodotwórstwo zakładało więc politykę asymilacyjną (Danilov, 2000; Kołodziejczyk, 2000, s. 147; Cagaptay, 2006; Bora, 2014).

Ayhan Kaya proponuje natomiast bardziej złożone podejście w studiach nad diasporą czerkieską w Turcji. Jego ustalenia mogą zostać również zastosowane do diaspory czerkieskiej zamieszkującej Izrael i Syrię, a w niewielkim stopniu - Jordanię. W zrozumieniu specyfiki tej grupy mają pomóc narzędzia zaczerpnięte ze studiów nad diasporami i globalizacją. Turecki antropolog proponuje zestawienie stworzonej przez Williama Safrana definicji diaspory z tureckimi Czerkiesami. Według typu idealnego Safrana diaspora to „wysiedlona wspólnota mniejszościowa", która

(1) opuściła swoje pierwotne centrum na rzecz co najmniej dwóch miejsc o charakterze peryferyjnym;

(2) podtrzymuje pamięć, wizję i mit pierwotnej ojczyzny;

(3) wierzy, że nie jest w pełni akceptowana przez większość w kraju przyjmującym;

(4) w ojczyźnie przodków upatruje miejsca powrotu, gdy nastąpi dogodny moment;

(5) czuje się zobowiązana do podtrzymania i odbudowy ojczyzny;

(6) jest świadoma wewnętrznie i solidarna z utraconą ojczyzną.

Kaya dowodzi, że podany typ idealny można zastosować do społeczności czerkieskiej w Turcji. Po pierwsze, Czerkiesi żyją również na Bliskim Wschodzie, Bałkanach, w Europie Zachodniej, Stanach Zjednoczonych i Australii. Po drugie, podtrzymują pamięć, wizję i mit ojczyzny, o czym świadczy rosnąca liczba publikacji na temat ich własnej historii oraz istniejące organizacje narodowe. Po trzecie, coraz częściej podnoszą kwestię powrotu do ojczyzny; ten punkt jest jednak dyskusyjny - przynajmniej w odniesieniu do znacznej części Czerkiesów tureckich, a ewentualny powrót jedynie częściowo oddaje poczucie wrogości ze strony większości tureckiej. Po czwarte, Czerkiesi zawsze mówili o powrocie do ojczyzny, potomkowie muchadżyrów podtrzymują ten postulat, a ponadto niektórzy z nich już do niej wrócili. Po piąte, organizacje czerkieskie inwestują na Kaukazie. Po szóste, Czerkiesi jako swoją ojczyznę podają Czerkiesję, odbierają radio nadające z Kaukazu, a także wysyłają tam swoją młodzież na studia (Kaya, 2005).

Z drugiej strony Kaya proponuje kolejne narzędzie, jakim są studia nad globalizacją. Używa pojęcia „oddolnej globalizacji”, której przypisuje pełnienie kluczowej roli w rozwoju świadomości diaspory, jednocześnie łamiąc hegemonię opresyjnego dla mniejszości etnicznych państwa narodowego. Ponadto, globalizacja łamie również bipolarny porządek postrzegania rzeczywistości opartej na dychotomii: „kraj przebywania - stara ojczyzna”, zastępując go wizją wielobiegunową, w której dużą rolę odgrywają przedstawiciele diaspory w innych częściach świata. Świadomość kształtuje się zatem w oparciu o kontakty z republikami Kaukazu Północnego: wspomniane stacje radiowe nadające z Kaukazu 
są słuchane w Turcji, istnieją połączenia lotnicze, promy pływające do Soczi i Suchumi, publikacje rozpowszechniane przez Międzynarodowe Stowarzyszenie Czerkieskie są szeroko dostępne, a nauczyciele tańców ludowych sprowadzani są z Kaukazu (Kaya, 2005). Zaproponowany przez Kayę aparat daje nam ramy do zrozumienia współczesnej diaspory czerkieskiej w Republice Tureckiej i jej obecnej sytuacji. Z pewnymi modyfikacjami można go również zastosować do Czerkiesów syryjskich i izraelskich.

Jak wspomniano, turecki nacjonalizm ma charakter ekskluzywny i asymilacyjny. Przez długie lata taki stan rzeczy powodował, że jakiekolwiek prawa mniejszości narodowych były ignorowane, na czym w największym stopniu ucierpieli Kurdowie. Czerkiesi uchodzący jednak za lojalnych obywateli republiki również byli pod tym względem długo dyskryminowani. Język - o ile jeszcze go znano - używany był jedynie w sferze domowej, a próby publicznego zaznaczenia swojej odrębności kończyły się sankcjami bądź to państwa, bądź nacjonalistycznej części społeczeństwa8 ${ }^{8}$. Wzrost aktywizacji politycznej Czerkiesów nastąpił jednak w ostatnich dwóch dekadach, w związku z upadkiem ZSRR i otwarciem granic. W ten sposób otworzyły się kolejne możliwości rozwijania kontaktów z historyczną ojczyzną.

Kilkukrotnie wspominany tutaj Ayhan Kaya pokazuje również, jak wzrost politycznej partycypacji Czerkiesów wpłynął na rozwój nacjonalizmu. Po II wojnie światowej w republice Tureckiej działały organizacje skupiające ludność pochodzącą z całego Kaukazu, akcentujące swój antyradziecki charakter. Ich powstanie było również reakcją na politykę asymilacji zakładającą między innymi nadawanie tureckich imion, posyłanie dzieci do tureckich szkół, posługiwanie się wyłącznie językiem tureckim. W latach siedemdziesiątych organizacje te dzieliły się na narodowe i radykalne (socjalistyczne, rewolucyjne) (Kaya, 2004). Rozwój świadomości został zablokowany przez wojskowy zamach stanu z 12 września 1980 r. W tym samym czasie do głosu zaczął dochodzić radykalny nacjonalizm kurdyjski. Pod sztandarami Partii Pracujących Kurdystanu separatyści kurdyjscy rozpoczęli w roku 1984 walkę partyzancką. Polityka władz tureckich wobec wszystkich mniejszości nabrała wówczas nowego wymiaru. Odmienności etniczne zaczęto negować coraz ostrzej, a wszelkie próby ich zamanifestowania postrzegane były jako zamach na integralność terytorialną państwa (Kaya, 2004). Kaya wyróżnia dwa rodzaje tureckiego nacjonalizmu funkcjonującego w tamtym czasie: oficjalny (państwowy, kemalistowski) i popularny. Pierwszy z nich zakładał wzmocnienie wysiłków asymilacyjnych przez państwo, drugi zaś wiązał się ze wzrostem niechęci społeczeństwa tureckiego do wszelkich mniejszości etnicznych podnoszących hasła polityczne. Przyczyną jego rozwoju było nasilenie się walki kurdyjskich partyzantów i antykurdyjska propaganda państwowa (Kaya, 2004). Od lat dziewięćdziesiątych Czerkiesi, podobnie jak inne mniejszości, znaleźli nowy kanał udziału w życiu politycznym w postaci polityki ds. mniejszości, jaką było prowadzono w okresie demokratyzacji. Czerkiesom i innym mniejszościom zezwolono na założenie własnych organizacji. Do najważniejszych z nich należą Kafkas Kültür Derneği (Kaukaskie Stowarzyszenie Kulturalne), zrzeszające kilkadziesiąt mniejszych stowarzyszeń oraz Fundacja Kaukaska (Kafkas Vakfi), a także Stowarzyszenie Zjednoczonego Kaukazu (Birleşik Kafkasya Derneğı). Działalność pierwszej z wymienionych organizacji została przybliżona powyżej, dwie pozostałe natomiast mają charakter religijny i w czasie dwóch wojen czeczeńskich wspierały separatystów (Kaya, 2004). Niewykluczone, że w dalszym ciągu wspierają one kolejne inkarnacje Czeczeńskiej Republiki Iczkerii, w tym wypadku Emirat Kaukaski.

Szczególne nasilenie tego typu postaw w społeczeństwie tureckim miało miejsce w latach siedemdziesiątych XX stulecia, kiedy organizacje czerkieskie stawały się obiektem ataków skrajnych nacjonalistów tureckich. Najbardziej radykalnym tego przykładem był atak w listopadzie 1977 r. w Ankarze. W jego wyniku żywcem spłonął lewicujący aktywista czerkieski Tsey Mahmut Özden (Melgoş, 2009). 
Początki czerkieskiego ruchu narodowego na Kaukazie Północnym sytuuje się we wczesnych latach dziewięćdziesiątych i, jak nietrudno się domyślić, związane są z upadkiem ZSRR. Rozwój adygejskiej, a także abchasko-adygejskiej solidarności zintensyfikowała wojna w Abchazji, w której uczestniczyli ochotnicy z Kaukazu Północnego. Wśród nich znajdowali się Szamil Basajew, ale również pochodzący z Kabardyno-Bałkarii Ibragim Jaganow (obecnie szef republikańskiego Adyge Chase w republice) oraz Jurij "Musa" Szanibow - jedna z najistotniejszych postaci czerkieskiego nacjonalizmu. Wszyscy wyżej wspomniani otrzymali tytuły „Bohaterów Abchazji”. Szczególnie istotna jest tutaj działalność Szanibowa. Jego biografia pokazuje sposób, w jaki ewoluowały poglądy przedstawicieli czerkieskich elit narodowych. Georgi Derluguian nazwał go "Garibaldim Kaukazu Północnego". Szanibow w latach sześćdziesiątych był kontestatorem władzy radzieckiej, daleki był jednak od nacjonalizmu. Zaczytywał się w tekstach autorów związanych z francuską Nową Lewicą. Dopiero wojna w Abchazji spowodowała, że zwrócił się ku idei narodowej. Jej późniejsze zakończenie zmusiło go jednak do wewnętrznej emigracji i powrotu na uniwersytet (Derluguian, 2005, ss. 1-29). Katastrofalna sytuacja gospodarcza i rozkład społeczny po upadku ZSRR spowodowały zatem rozwój etnicznych i narodowych partykularyzmów, objawiający się w częstych konfliktach i kryzysach politycznych w republikach, gdzie ludność adygejska i turkijska (Karaczajowie i Bałkarzy) stanowiła narody tytularne. Nie inaczej sytuacja rozwinęła się w Adygei, gdzie Adygejczycy stanowią jedyny naród tytularny, choć ich populacja wynosi zaledwie ok. 20\% mieszkańców republiki.

Adygea jest jednak przypadkiem zasługującym na osobną uwagę. W okresie radzieckim miała status obwodu autonomicznego. Po rozpadzie ZSRR władze tej jednostki administracyjnej ogłosiły podniesienie obwodu do rangi republiki. Jednocześnie ustalono, że urzędowym językiem będzie tu obok rosyjskiego również czerkieski, a kandydat na stanowisko prezydenta musi się tym językiem biegle posługiwać. Dla dorosłego Słowianina nauczenie się języka z rodziny kaukaskiej jest prawie niemożliwe. Elitom adygejskim udało się zdobyć władzę symboliczną w republice (Richmond, 2008, ss. 144-146). Antropologiczny wymiar tego, czym była republika w systemie radzieckim nie pozostaje tutaj bez znaczenia. Yuri Slezkine pokazał, w jaki sposób w ZSRR rozgrywano etniczne partykularyzmy. W jednym ze swoich artykułów dowodzi, że Związek Radziecki był czymś na kształt mieszkania komunalnego, które miało rosyjskojęzyczny korytarz, a pokoje miały etniczny charakter. Znaczy to tyle, że nazwa „Związek Socjalistycznych Republik Radzieckich" pozbawiona była desygnatów etnicznych i terytorialnych. Poszczególne jego składowe natomiast wydzielane były wyłącznie na bazie tych kryteriów. Język rosyjski był de facto dominującym, nigdy jednak nie przyznano tego de iure (Slezkine, 1994). Dlatego też sama kategoria republiki zawierała w sobie „niespełnioną obietnice czystości etnicznej"9. Innymi słowy, bycie narodem tytularnym oznaczało tyle, że jest się gospodarzem, a przedstawiciele innych grup etnicznych, z Rosjanami włącznie to tylko goście. W oparciu o tę zasadę adygejskie elity polityczne dokonały przejęcia symbolicznej władzy w republice, gdzie mimo iż pozostają mniejszością, to zajmują uprzywilejowaną pozycję do dziś.

\footnotetext{
9 W takich słowach określit to dr Iwan Pieszkow, któremu jestem winien podziękowanie za zwrócenie uwagi na ten wymiar radzieckiego systemu politycznego.
} 
Powyżej nakreślony został charakter nacjonalizmu czerkieskiego na Kaukazie Północnym i w diasporze. Pominięta została europejska i amerykańska część narodu czerkieskiego. Jak widać, obecnie Czerkiesi żyjący w swojej historycznej ojczyźnie i poza nią funkcjonują w odmiennych kontekstach politycznych, kulturowych i społecznych. Tym, co spaja wszystkich jest świadomość, że przynależą do wspólnoty wyobrażonej. Ta z kolei rozwija się w ciągu ostatnich dwóch dekad za sprawą rozwoju środków masowej komunikacji. Dlatego też można w tym miejscu powrócić do uwag zawartych we wstępie artykułu. Nacjonalizm czerkieski może być transnacjonalizmem, dlatego że różne grupy ludności pochodzącej z północnego Kaukazu żyją w różnych miejscach na świecie, są członkami różnych społeczeństw, ale w mniejszym lub większym stopniu zachowują jeśli nie odrębność, to przynajmniej świadomość swojego pochodzenia. Ta jest zaś motorem do politycznej aktywności, której najlepszym przykładem były protesty przeciwko organizacji zimowych igrzysk olimpijskich w Soczi. Stoki narciarskie zostały wybudowane na masowych grobach czerkieskich wojowników w pobliżu dawnej stolicy Czerkiesów. Protestowano w Nowym Jorku, Stambule, a także w miastach zachodniej Europy. Nacjonalizm czerkieski zrodzit się w XIX stuleciu za sprawą działalności Davida Urqhuarta - szkockiego szpiega, który zaprojektował zielony sztandar, będący dzisiaj flagą Republiki Adygei (King, 2007). W tym wypadku mamy do czynienia z klasycznym przykładem tradycji wynalezionej. Z drugiej strony wykorzystywanie takich mediów jak Facebook czy YouTube oraz strona CircassianWorld.com (Besleney, 2010), może być widziane jako współczesna wersja wynalazku druku, który wedle interpretacji Benedicta Andersona miał kluczowe znaczenie dla rozwoju wspólnoty wyobrażonej. Wspólnota taka rozwija się już nie w obrębie państwa narodowego, ale ponad nim i mimo opisywanych wyżej różnic w życiu codziennym pozostaje żywa jako wirtualny byt mobilizujący społeczności dzielące przekonanie o przynależności do konkretnej grupy - a przez to wpływa na ich działalność polityczną.

\section{BIBLIOGRAFIA}

Arseven, C. (2013, luty 17). Yeni Çerkesya Türkiye. Hürriyet Pazar.

Arutiunov, S. A. (2010, styczeń 24). Zakliuchenie RAN ob ètnonime Cherkes i toponime Cherkesiia. Pobrano 11 stycznia 2014, z http://aheku.org/page.php?id=2080

Baderkhan, F. (2001). Severokavkazkaia diaspora v Turtsii, Sirii i lordanii: Vtoraia polovina XIX - pervaia polovina XX veka. Moskva: IV RAN.

Besleney, Z. A. (2010, maj 5). Circassian nationalism and the Internet. Pobrano 10 grudnia 2014, z http://www.opendemocracy.net/od-russia/zeynel-abidin-besleney/circassiannationalism-and-internet

Bobrovnikov, V. (2000). Abreki i gosudarstvo: Kul'tura nasiliia na Kavkaze. Vestnik Evrazii, 1(8), 19-46

Bora, T. (2014). İnşa Döneminde Türk Millî Kimliği. W T. Bora, Türk Sağının Üç Hali: Milliyetçilik, Muhafazakârlık, Islâmcılık (ss. 13-53). Istanbul: İletişim.

Bram, C. (1999). Circassian re-immigration to the Caucasus. W S. Weil (Red.), Routes and roots: Emigration in a global perspective (ss. 205-222). Jerusalem: Magnes. 
Cagaptay, S. (2006). Islam, secularism, and nationalism in modern Turkey: Who is a Turk? London: Routledge.

Danilov, V. I. (2000). Metamorfozy turetskogo natsionalizma. W V. A. Isaev \& A. O. Filonik (Red.), Blizhnil Vostok i sovremennost': Sbornik stateĭ (9. wyd., ss. 20-35). Moskva: IlliBV.

Derluguian, G. (2005). Bourdieu's secret admirer in the Caucasus: A world-system biography. Chicago, London: Chicago University Press.

Doğan, S. N. (2010). From national humiliation to difference: The image of the Circassian beauty in the discourses of Circassian diaspora nationalists. New Perspectives on Turkey, (42), 77-101.

Gellner, E. (2009). Narody i nacjonalizm. (T. Hołówka, Tłum.). Warszawa: Difin.

Górecki, W. (2010). Planeta Kaukaz. Wołowiec: Wydawnictwo Czarne.

Gurguliia, Ė. (b.d.). Cherkesskie diaspory v stranakh Vostoka. Pobrano 20 stycznia 2014, z http://www.central-eurasia.com/karachaevo-cherkessia/?uid=352

Kaliszewska, I., \& Falkowski, M. (2010). Matrioszka w hidżabie: Reportaże z Dagestanu iCzeczenii. Warszawa: Sic!

Kaya, A. (2004). Political participation strategies of the Circassian diaspora in Turkey. Mediterranean Politics, 9(2), 221-239. http://doi.org/10.1080/1362939042000221286

Kaya, A. (2005). Circassian diaspora in Turkey: Stereotypes, prejudices and ethnic relations. W N. Kuran-Burçoğlu \& S. G. Miller (Red.), Representations of the "Other/s" in Mediterranean world and their impact on the region (ss. 217-240). Istanbul: The ISIS Press.

King, C. (2007). Imagining Circassia: David Urquhart and the making of North Caucasus nationalism. Russian Review, 66(2), 238-255. http://doi.org/10.1111/j.14679434.2007.00440.x

King, C. (2008). Widmo wolności: Historia Kaukazu. (A. Czwojdrak, Tłum.). Kraków: Wydawnictwo Uniwersytetu Jagiellońskiego.

Kołodziejczyk, D. (2000). Turcja. Warszawa: Wydawnictwo Trio.

Konstitutsiia Rossiĭskoĭ Federatsii. (b.d.). Pobrano 20 grudnia 2014, z http://constitution. kremlin.ru

Kushkhabiev, A. V. (2007). Ocherki istorii zarubezhnoĭ cherkesskoĭ diaspory: Monografiia. Nalchik: Ėl'-Fa.

Lewellen, T. (2013). Antropologia polityczna: Wprowadzenie. (A. Dąbrowska \& T. Sieczkowski, Tłum.). Kraków: Wydawnictwo Uniwersytetu Jagiellońskiego.

Marszewski, M. (2010, luty 18). Islam północnokaukaskich diaspor. Pobrano 11 stycznia 2014, z http://www.pia.org.pl/publikacje/131-islam-polnocnokaukaskich-diaspoMelgoş, B. (2009). 12 Eylül'e Doğru Ankara Kafkas Derneği: Bazı Notlar ve Belgeler. Nart Dergisi, (68).

Nefliasheva, N. (2012a, styczeń 6). Mission possible. Sirĭ̌skie cherkesy - doroga domoĭ. Pobrano 17 grudnia 2014, z http://www.kavkaz-uzel.ru/blogs/1927/posts/10274

Nefliasheva, N. (2012b, styczeń 21). Cherkesskoe natsional'noe dvizhenie - rossiīskiĭ i mezhdunarodnyı̆ kontekst. Pobrano 12 grudnia 2014, z http://www.aheku.org/page. php?id=2813

Nefliasheva, N. (2012c, wrzesień 13). Siriĭskie cherkesy i problema repatriatsii. Pobrano 12 grudnia 2014, z http://www.carnegie.ru/publications/?fa=49368 
Nefliasheva, N. (2012d, listopad 18). Cherkesskie pikety $\vee$ Moskve kak transformatsiia zeklué. Pobrano 28 listopada 2013, z http://www.kavkaz-uzel.ru/blogs/1927/ posts/13146

Nosova, S. (2012, styczeń 31). Kushkhabiev: polozhenie cherkesov Sirii usugubliaetsia ikh neĭtral'noĭ pozitsiě v konflikte. Pobrano 17 grudnia 2014, z http://www.kavkaz-uzel.ru/ articles/200240/

Pstrusińska, J. (1977). Paštunwali - afgański kodeks postępowania. Etnografia Polska, 21(2), 63-79.

Richmond, W. (2008). The Northwest Caucasus: Past, present, future. London, New York: Routledge.

Safran, W. (1991). Diasporas in modern societies: Myths of homeland and return. Diaspora: A Journal of Transnational Studies, 1(1), 83-99. http://doi.org/10.1353/ dsp.1991.0004

Shenfield, S. D. (1999). Circassians - a forgotten genocide? W M. Levene \& P. Roberts (Red.), The massacre in history (ss. 149-163). New York: Berghahn Book.

Shnirel'man, V. (2003). Voinny pamiati: Mify, identichnost' i politika v Zakavkaz'e. Moskva: IKTS Akademkniga.

Shnirel'man, V. (2006). Byt' alanami: Intellektualy i politika na Severnom Kavkaze v XX veke. Moskva: Novoe literaturnoe obozrenie.

Sierakowska-Dyndo, J. (2007). Granice wyobraźni politycznej Afgańczyków: Normatywnoaksjologiczne aspekty tradycji afgańskiej. Warszawa: Wydawnictwa UW.

Sierakowska-Dyndo, J. (2008). Afganistan - w objęciach czy w szponach tradycji? Poznań: Centrum Badań Środkowoazjatyckich UAM.

Slezkine, Y. (1994). The USSR as a communal apartment, or how a socialist state promoted ethnic particularism. Slavic Review, 53(2), 414-452. http://doi.org/10.2307/2501300

Tishkov, V. (2000). Forget the 'nation': Post-nationalist understanding of nationalism. Ethnic and Racial Studies, 23(4), 625-650. http://doi.org/10.1080/01419870050033658

Zürcher, E. J. (2013). Turcja: Od suttanatu do wspótczesności. (A. Gąsior-Niemiec, Tłum.). Kraków: Wydawnictwo Uniwersytetu Jagiellońskiego. 